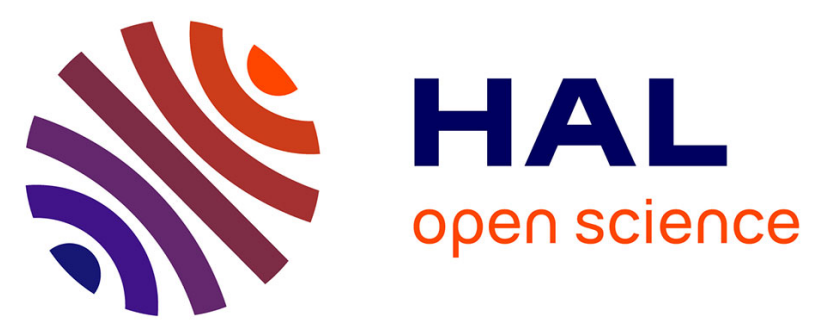

\title{
The evolution pathway from iron compounds to Fe 1 (II)-N 4 sites through gas-phase iron during pyrolysis
} Lynne Larochelle Richard, Moulay Tahar Sougrati, Jingkun Li, Li Jiao, Evan

Wegener, Lynne Larochelle Richard, Ershuai Liu, Andrea Zitolo, Moulay Tahar Sougrati, Sanjeev Mukerjee, et al.

\section{To cite this version:}

Lynne Larochelle Richard, Moulay Tahar Sougrati, Jingkun Li, Li Jiao, Evan Wegener, et al.. The evolution pathway from iron compounds to Fe 1 (II)-N 4 sites through gas-phase iron during pyrolysis. Journal of the American Chemical Society, 2020, 142 (3), pp.1417-1423. 10.1021/jacs.9b11197 . hal03008555

\section{HAL Id: hal-03008555 \\ https://hal.science/hal-03008555}

Submitted on 16 Nov 2020

HAL is a multi-disciplinary open access archive for the deposit and dissemination of scientific research documents, whether they are published or not. The documents may come from teaching and research institutions in France or abroad, or from public or private research centers.
L'archive ouverte pluridisciplinaire HAL, est destinée au dépôt et à la diffusion de documents scientifiques de niveau recherche, publiés ou non, émanant des établissements d'enseignement et de recherche français ou étrangers, des laboratoires publics ou privés. 


\section{The evolution pathway from iron compounds to $\mathrm{Fe}_{1}(\mathrm{II})-\mathrm{N}_{4}$ sites through gas-phase iron during pyrolysis}

Jingkun Li ${ }^{1,4, \#}, \mathrm{Li} \mathrm{Jiao}^{2}$, Evan Wegener ${ }^{3}$, Lynne Larochelle Richard ${ }^{4}$, Ershuai Liu $^{4}$, Andrea Zitolo ${ }^{5}$, Moulay Tahar Sougrati ${ }^{1}$, Sanjeev Mukerjee ${ }^{4}$, Zipeng Zhao ${ }^{6}$, Yu Huang ${ }^{6,7}$, Fan Yang ${ }^{8}$, Sichen Zhong ${ }^{8}$, Hui Xu ${ }^{8}$, A. $^{2}$ Jeremy Kropf ${ }^{3}$, Frédéric Jaouen ${ }^{1}$, Deborah J. Myers ${ }^{*, 3}$, and Qingying Jia ${ }^{*, 4}$

${ }^{1}$ Institut Charles Gerhardt Montpellier, UMR 5253, CNRS, Université Montpellier, ENSCM, Place Eugène Bataillon, 34095 Montpellier cedex 5, France

${ }^{2}$ Department of Chemical Engineering, Northeastern University, Boston, Massachusetts, 02115, United States

${ }^{3}$ Chemical Sciences and Engineering Division, Argonne National Laboratory, Lemont, Illinois, 60439, United States

${ }^{4}$ Department of Chemistry and Chemical Biology, Northeastern University, Boston, Massachusetts, 02115, United States

${ }^{5}$ Synchrotron SOLEIL, L'orme des Merisiers, BP 48 Saint Aubin, 91192 Gif-sur-Yvette, France

${ }^{6}$ Department of Materials Science and Engineering, University of California, Los Angeles, California, 90095, United States

${ }^{7}$ California NanoSystems Institute (CNSI), University of California, Los Angeles, California, 90095

${ }^{8}$ Giner, Inc, Newton, Massachusetts, 02466, United States.

${ }^{\#} 1$ is the present address of J.L.; 4 is the previous address.

ABSTRACT: Pyrolysis is indispensable for synthesizing highly active Fe-N-C catalysts for the oxygen reduction reaction (ORR) in acid, but how $\mathrm{Fe}, \mathrm{N}$, and $\mathrm{C}$ precursors transform to ORR-active sites during pyrolysis remains unclear. This knowledge gap obscures the connections between the input precursors and output products, clouding the pathway toward Fe-N-C catalyst improvement. Herein, we unravel the evolution pathway of precursors to ORR-active catalyst comprised exclusively of single atom $\mathrm{Fe}_{1}(\mathrm{II})-\mathrm{N}_{4}$ sites via intemperature X-ray absorption spectroscopy. The Fe precursor transforms to Fe oxides below $300{ }^{\circ}$, $\mathrm{Cand}$ then to tetrahedral $\mathrm{Fe}_{1}(\mathrm{II})-\mathrm{O}_{4}$ via a crystal-to-melt-like transformation below $600{ }^{\circ} \mathrm{CTh}$ - $\mathrm{Fe}_{1}(\mathrm{II})-\mathrm{O}_{4}$ releases a single Fe atom that diffuses into the $\mathrm{N}$-doped carbon defect forming $\mathrm{Fe}_{1}(\mathrm{II})-\mathrm{N}_{4}$ above $600^{\circ}$.CThis vapor phase single Fe atom transport mechanism is verified by synthesizing $\mathrm{Fe}_{1}(\mathrm{II})-\mathrm{N}_{4}$ sites via "non-contact pyrolysis" wherein the Fe precursor is not in physical contact with the $\mathrm{N}$ and C precursors during pyrolysis.

\section{INTRODUCTION}

Hydrogen fuel cell electric vehicles (FCEVs), based on proton exchange membrane fuel cells (PEMFCs), were first sold commercially in Japan in 2014, with the launch of the Toyota Mirai, ${ }^{1}$ followed by limited commercialization in Europe, Korea, Canada, and the United States in 2015 by both Toyota and Hyundai. The catalysts used for the oxygen reduction reaction (ORR) in PEMFCs are Pt-alloys. ${ }^{1}$ While advances have been made in reducing platinum usage in PEMFCs, the cost of automotive fuel cell systems is still prohibitively high, due primarily to the high loading of Pt in the PEMFC cathode. ${ }^{1,2}$ The key to widespread and sustainable commercialization of FCEVs from a cost perspective is the significant reduction of Pt loading $^{2}$ or the replacement of Pt-alloys with earth-abundant, inexpensive materials (i.e., platinum group metal (PGM)-free). The leading PGM-free catalysts for the ORR in PEMFCs are single transition metal atoms $(\mathrm{M}=\mathrm{Mn}, \mathrm{Fe}$ or $\mathrm{Co})$ embedded in a nitrogen-doped carbon matrix (M-N-C). ${ }^{3.9}$ Recently, Ye et al. ${ }^{9}$ reported an Fe-N-C catalyst that delivers $570 \mathrm{~mW} \cdot \mathrm{cm}^{-2}$ in $\mathrm{H}_{2} /$ air PEMFCs. Nevertheless, this state-of-the-art performance is insufficient for automotive PEMFCs. ${ }^{2}$ Further progress in per- formance necessitates improvements in the turnover frequency and/or in the density of active sites in M-N-C materials, both of which are impeded by the lack of understanding of the formation of the active site(s) in the synthesis of M-N-C catalysts. The current synthesis strategies for M-N-C catalysts consist of combining sources of $\mathrm{M}, \mathrm{N}$, and $\mathrm{C}$ either in a single compound or in separate compounds and pyrolyzing the compound(s) typically in the 900 to $1100{ }^{\circ} \mathrm{C}$ temperature range. ${ }^{6.8,10,11}$ These synthesis strategies primarily rely on an empirical approach to choice of precursor, $\mathrm{M}$ content, and pyrolysis settings to increase catalytic activity. The underlying mechanism governing the competitive formation of metal-based active sites and byproducts during pyrolysis has remained elusive. Rational synthesis of improved M-N-C catalysts requires unraveling the current "black box" synthesis approach of input precursors and output products.

The complexity of M-N-C catalyst structures arises largely from the pyrolysis process, which was demonstrated in the 1980s to be essential to producing highly active M-N-C catalysts for the ORR in acidic media. ${ }^{11}$ The material resulting from the high temperature pyrolysis, however, is often a mixture of species including $\mathrm{N}$-doped carbon defects or edges, $\mathrm{M}-\mathrm{N}_{\mathrm{x}}$ moieties, 
and inorganic particles of metal, metal oxides, carbides, nitrides, etc. ${ }^{12-17}$ All these species have been proposed to be ORR active in alkaline and even in acidic electrolyte., 10, 12-19 It thus remains inconclusive which site(s) are responsible for the superior ORR activity of M-N-C catalysts. This issue has been addressed by efforts to gain some control over the final products. By lowering the Fe content in the precursors ( $<1 \mathrm{wt} \%)$, some research groups managed to produce Fe-N-C catalysts with predominately $\mathrm{Fe}_{1}(\mathrm{II})-\mathrm{N}_{4}$ ( $\mathrm{Fe}_{1}$ denotes the single atom configuration without direct Fe-Fe bonds) moieties, as evidenced by ${ }^{57} \mathrm{Fe}$ Mössbauer and X-ray absorption spectroscopy (XAS). 6, 10, 19, 20 These catalysts exhibit high ORR performance despite their low gravimetric and volumetric density of $\mathrm{Fe}_{1}(\mathrm{II})-\mathrm{N}_{4}$ sites. Recently, $\mathrm{Fe}_{1}$ (II)- $\mathrm{N}_{4}$ moieties were visualized in the Fe-N-C catalyst by scanning transmission electron microscopy coupled with electron energy loss spectroscopy. ${ }^{3}$ These studies indicate that the $\mathrm{Fe}_{1}(\mathrm{II})-\mathrm{N}_{4}$ moiety has a high turnover frequency towards the ORR and likely is the major contributor to the ORR activity of pyrolyzed Fe-N-C catalysts. This finding identifies an obvious pathway towards Fe-N-C catalyst advancement via increasing the $\mathrm{Fe}_{1}$ (II)- $\mathrm{N}_{4}$ site density. However, the electrochemically active $\mathrm{Fe}_{1}(\mathrm{II})-\mathrm{N}_{4}$ site density saturates at a very low Fe content $(<3$ wt\%), ${ }^{6} 20$ despite substantial efforts to optimize the type and composition of precursors and pyrolysis conditions. The marginal improvement in Fe-N-C catalysts reported in recent years using the trial-and-error synthesis approach calls for a return to the original question: how is the $\mathrm{Fe}_{1}$ (II)- $\mathrm{N}_{4}$ site formed during pyrolysis? Herein, we directly monitor the stepwise transformation from $\mathrm{Fe}$ precursors to $\mathrm{Fe}_{1}(\mathrm{II})-\mathrm{N}_{4}$ sites during pyrolysis and validate our site formation mechanistic model via "noncontact pyrolysis" where the Fe and C-N precursors are not in physical contact during pyrolysis.

\section{RESULTS AND DISCUSSION}

In-temperature XAS at the Fe K-edge was measured on the mixture of $\mathrm{Fe}, \mathrm{N}$, and $\mathrm{C}$ precursors throughout the pyrolysis and cooling processes and after exposure of the material to air at room temperature after the pyrolysis. We gradually increased the temperature of the samples to $1000{ }^{\circ} \mathrm{C}$ and then decreased the temperature to room temperature in a flowing Helium atmosphere, holding at targeted temperatures during XAS measurements. Two different routes were chosen for in temperature XAS measurements. The first route used a mixture of iron(II) acetate $\left(\mathrm{FeAc}_{2}\right), 1,10$-phenanthroline monohydrate, and a Zn-based metal organic framework (MOF), zeolitic imidazolate framework eight (ZIF-8), mixed via ball milling (see Supplementary). These precursors are typical for synthesis of MOF-derived Fe-N-C catalysts, $6,10,15,20$ and have been shown to generate active $\mathrm{Fe}-\mathrm{N}-\mathrm{C}$ catalysts with predominantly $\mathrm{Fe}_{1}(\mathrm{II})-\mathrm{N}_{4}$ sites. ${ }^{6,10,20}$ However, with this route, the thermal evolution of the $\mathrm{Fe}$ compound is convoluted with the thermal evolution of the $\mathrm{N}$ and $\mathrm{C}$ precursors. To deconvolute the effect of pyrolysis on the Fe and C-N constituents, the second route used a mixture of $\mathrm{FeCl}_{2} \cdot 4 \mathrm{H}_{2} \mathrm{O}$, as the iron precursor not containing $\mathrm{N}$ and $\mathrm{C}$, and a heat-treated $\mathrm{N}$-doped carbon matrix (N-C) as the $\mathrm{N}$ and $\mathrm{C}$ precursor. Following the procedure developed for pyrolysis of MOF-derived Fe-N-C catalysts, ${ }^{10,}{ }^{20}$ the N-C was synthesized by homogenizing ZIF-8 and 1,10-phenanthroline dry powders via low-energy planetary ball-milling, followed by heat treatment in $\mathrm{Ar}$ at $1050{ }^{\circ} \mathrm{C}$ for one hour and a second heat treatment in $\mathrm{NH}_{3}$ at $900{ }^{\circ} \mathrm{C}$ for 15 minutes. Multiple characterizations (Figure S1) showed that the N-C has a porous structure with a Brunauer-Emmett-Teller (BET) surface area of $950 \mathrm{~m}^{2} \cdot \mathrm{g}^{-1}$, of which $770 \mathrm{~m}^{2} \cdot \mathrm{g}^{-1}$ is contributed from micropores according to the t-plot analysis (Figure S1E). X-ray photoelectron spectroscopy (XPS) indicated 0.46 at\% of residual $\mathrm{Zn}, 2.86$ at $\%$ of $\mathrm{O}$, 6.51 at $\%$ of $\mathrm{N}$, and, notably, an ultra-high content of pyridinic $\mathrm{N}$, as manifested by the prominent peak at $398.3 \mathrm{eV}$ (Figure S1D). ${ }^{21}$ The simultaneous presence of abundant micropores and pyridinic $\mathrm{N}$ preferentially located at the defects and edges of the carbon matrix ${ }^{22}$ signifies the presence of abundant nitrogen-doped microporous defects. ${ }^{21}$

XAS of the $\mathrm{FeCl}_{2} \cdot 4 \mathrm{H}_{2} \mathrm{O}$ and N-C mixture. As compared to the as-received $\mathrm{FeCl}_{2} \cdot 4 \mathrm{H}_{2} \mathrm{O}$, the $\mathrm{FeCl}_{2} \cdot 4 \mathrm{H}_{2} \mathrm{O}$ mixed with $\mathrm{N}-\mathrm{C}$ via ball-milling exhibits a much lower peak intensity of the X-ray absorption near edge structure (XANES) spectrum at room temperature (Figure 1A). Meanwhile, the intensity of the Fe-O ( $\mathrm{O}$ from $\mathrm{H}_{2} \mathrm{O}$ ) scattering, with a peak at approximately $1.5 \AA$ Ain the Fourier transform of the extended X-ray absorption fine structure (FT-EXAFS, note that the distances in the FT-EXAFS are not corrected for phase shift), drops dramatically; whereas the Fe-Cl scattering peak at approximately 2.1 Åremains largely unchanged (Figure 1B). These results indicate that ligating water molecules are partially detached upon ball-milling. As the temperature increases to $300{ }^{\circ} \mathrm{Cdenoted}$ as $\mathrm{FeCl}_{2}$-NC-300), the Fe-Cl scattering peak disappears, and new peaks emerge. The Fe-O peak at $1.4 \AA$ And the newly-emerging Fe-Fe peaks at $2.7 \AA$ and $4.6 \AA$ overlap those of the $\mathrm{aFe}_{2} \mathrm{O}_{3}$ standard (Figure 1B). Meanwhile, the edge energy increases and the XANES spectrum approaches that of $\mathrm{GFe}_{2} \mathrm{O}_{3}$ (Figure 1A). These results indicate that ferric oxides are formed at $300^{\circ} \mathrm{CAs}$ the temperature gradually increases to $600{ }^{\circ}$,Cthe XANES shifts to lower energy approaching that of the $\mathrm{Fe}(\mathrm{II}) \mathrm{O}$ standard (Figure 1A), indicating the reduction of ferric oxides to ferrous oxides. The intensities of both the $\mathrm{Fe}-\mathrm{O}$ and $\mathrm{Fe}-\mathrm{Fe}$ peaks drop, with the Fe-Fe peaks eventually disappearing at $600{ }^{\circ}, \mathrm{Cleaving}$ behind one prominent peak at $1.5 \AA$ (Figure $1 \mathrm{~B}$ ). The peak can be fit well with an $\mathrm{Fe}-\mathrm{O}$ path with a bond distance of $1.99 \pm 0.01$ Åand a coordination number of 3.6 \pm 0.4 (Table S2 and Figure S2). This Fe-O configuration was previously reported, in molten $\mathrm{Fe}$ salts, to be a tetrahedral $\mathrm{Fe}(\mathrm{II})-\mathrm{O}_{4}$ moiety with an $\mathrm{Fe}-\mathrm{O}$ bond distance of $1.98 \pm 0.02 \AA^{23}$ The tetrahedral structure of the $\mathrm{Fe}_{1}(\mathrm{II})-\mathrm{O}_{4}$ species observed at $600{ }^{\circ} \mathrm{G}$ s supported by the high intensity of the $1 \mathrm{~s} \rightarrow$ $3 \mathrm{~d}$ transition feature of XANES at $7112 \mathrm{eV}$, as this feature is minimal for centrosymmetric Fe species, such as the in-plane $\mathrm{Fe}_{1}(\mathrm{II})-\mathrm{N}_{4}$ in iron phthalocyanine ( $\mathrm{FePc}$ ), and is intense in noncentrosymmetric Fe species, especially for the tetrahedral geometry (Figure S3). ${ }^{13,23}$ The observed transition from ferric oxides, with a local structure of octahedral $\mathrm{Fe}-\mathrm{O}_{6}$ with $\mathrm{Fe}-\mathrm{Fe}$ bonds, to tetrahedral $\mathrm{Fe}_{1}(\mathrm{II})-\mathrm{O}_{4}$, without $\mathrm{Fe}-\mathrm{Fe}$ bonds, is akin to the crystal-to-melt transition of $\mathrm{Fe}$ salts to $\mathrm{Fe}(\mathrm{II})-\mathrm{O}_{4}$ upon melting above $1300{ }^{\circ} \mathrm{C}^{3}$ Here the $\mathrm{Fe}_{1}(\mathrm{II})-\mathrm{O}_{4}$ is not in a molten state since it is observed at much lower temperature. Moreover, $\mathrm{Fe}_{1}(\mathrm{II})-\mathrm{O}_{4}$ is unstable by itself owing to the unbalanced cationic and anionic charge. It is rather stabilized by N-C in a solid state via electron delocalization that restores the charge balance, such as is observed for $\mathrm{Fe}_{1}$ (II)- $\mathrm{N}_{4}$ sites imbedded in a graphene plane. ${ }^{16}$

The in-plane $\mathrm{Fe}_{1}(\mathrm{II})-\mathrm{N}_{4}$ moieties emerge at approximately 600 ${ }^{\circ} \mathrm{CThis}$ is signified by the appearance of a peak at $7117 \mathrm{eV}$ in the first derivative of the XANES spectra, overlapping that of the 
Fe(II)-Pc standard (Figure 1C). This peak arises from the $1 \mathrm{~s}-4 \mathrm{p}_{z}$ transition with simultaneous ligand to metal charge transfer, and is the fingerprint of the in-plane $\mathrm{Fe}_{1}(\mathrm{II})-\mathrm{N}_{4}$ structure. ${ }^{12,13} \mathrm{As}$ the temperature increases to $1000{ }^{\circ}$, Cthe XANES spectrum at energies above $7117 \mathrm{eV}$ gradually shifts to higher energies, approaching that of $\mathrm{Fe}(\mathrm{II}) \mathrm{Pc}_{\mathrm{c}}$ (Figure 1A), indicating the transformation from the tetrahedral $\mathrm{Fe}_{1}(\mathrm{II})-\mathrm{O}_{4}$ to in-plane $\mathrm{Fe}_{1}(\mathrm{II})-\mathrm{N}_{4}$. This shift continues rather than reverses during cooling to room temperature, which indicates that the $\mathrm{Fe}_{1}(\mathrm{II})-\mathrm{O}_{4}-\mathrm{Fe}_{1}(\mathrm{II})$ $\mathrm{N}_{4}$ transformation is an irreversible thermal process. After cooling to room temperature, but before exposure to air, the $\mathrm{Fe}$ speciation $\left(\mathrm{FeCl}_{2}\right.$-NC-End) is dominated by in-plane $\mathrm{Fe}_{1}(\mathrm{II})-\mathrm{N}_{4}$ moieties, as verified by both the XANES and EXAFS spectra. The in-plane $\mathrm{Fe}_{1}(\mathrm{II})-\mathrm{N}_{4}$ fingerprint shoulder at $7117 \mathrm{eV}$ becomes prominent in the first derivative of the XANES (Figure $1 \mathrm{C})$ and even discernible in the XANES spectrum of $\mathrm{FeCl}_{2}-\mathrm{NC}$ End (Figure 1A). The EXAFS fitting (Figure S6) gives a first shell Fe-N coordination number of $4.3 \pm 0.4$ and bond length of $1.91 \pm 0.01 \AA$ close to that of Fe(II)Pc $\left(1.93 \pm 0.01 \AA^{20}\right.$ This Fe-N bond distance is much shorter than that of Fe-O $(1.99 \pm 0.01 \AA$ as expected from the in-plane structure versus the tetrahedral structure.
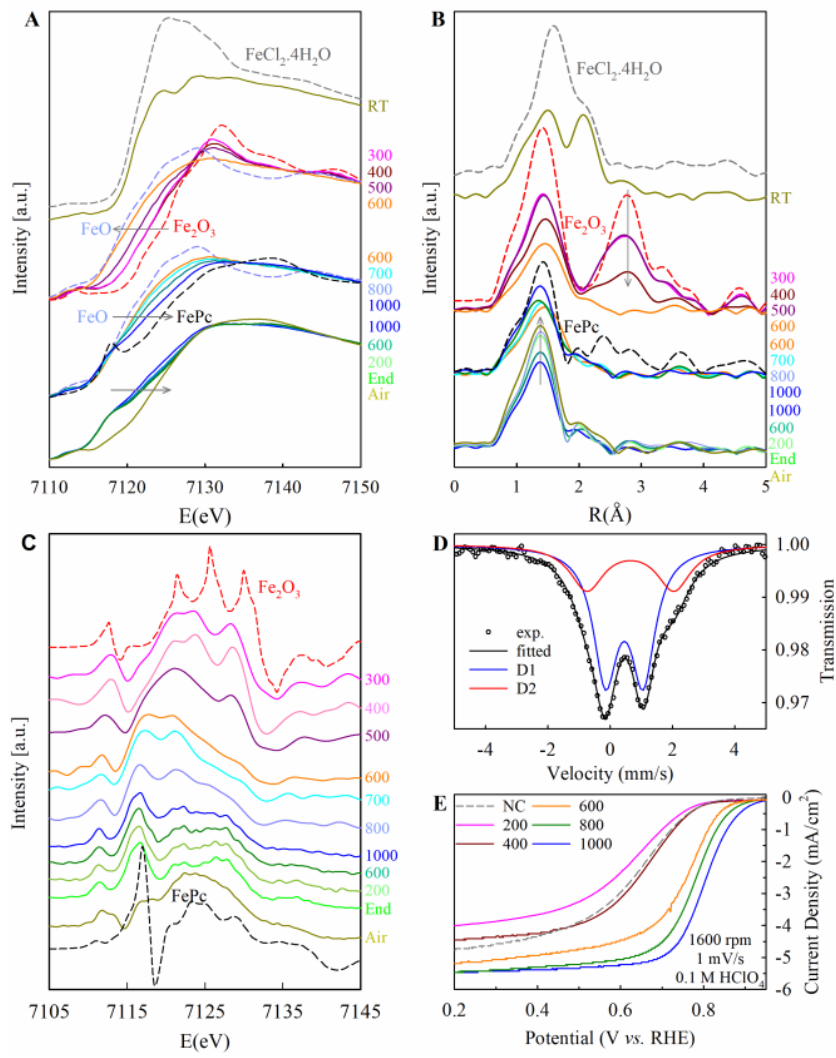

Figure 1. (A) XANES, (B) Fourier Transform (FT)-EXAFS and (C) the first derivative of the XANES spectra of $\mathrm{FeCl}_{2}$-NC-T collected with temperature increasing from room temperature to $1000^{\circ} \mathrm{G}$ nd cooling down to room temperature. (D) ${ }^{57} \mathrm{Fe}$ Mössbauer spectrum $(5 \mathrm{~K})$ and fitting of $\mathrm{FeCl}_{2}$-NC-Air. (E) ORR performance of $\mathrm{FeCl}_{2}$ NC-T catalysts. RDE polarization plots were obtained in room temperature $\mathrm{O}_{2}$-saturated $0.1 \mathrm{M} \mathrm{HClO}_{4}$ from 0.05 to $1.05 \mathrm{~V}$ with a scan rate of $1 \mathrm{mV} \cdot \mathrm{s}^{-1}$ at a rotation rate of $1,600 \mathrm{rpm}$. The corresponding cyclic voltammograms are displayed in Figure S4.
Upon exposure to air ( $\mathrm{FeCl}_{2}$-NC-Air), the XANES spectrum shifts positively and the fingerprint shoulder at $7117 \mathrm{eV}$ becomes barely discernible (Figure 1A), indicating the oxidation of the surface $\mathrm{Fe}_{1}$ (II)- $\mathrm{N}_{4}$ via adsorption of an $\mathrm{O}_{2}$ or $\mathrm{OH}$ ligand, forming $\mathrm{Fe}_{1}(\mathrm{III})-\mathrm{N}_{4}-\mathrm{O}_{2} / \mathrm{OH}$ sites. Low temperature $(5 \mathrm{~K})$ ex situ Mössbauer identifies two doublets D1 and D2 in $\mathrm{FeCl}_{2}$-NC-Air (Figure 1D and Table S3). D1 and D2 are the most common doublets identified in Fe-N-C materials and have recently been assigned to $\mathrm{Fe}_{1}(\mathrm{III})-\mathrm{N}_{4}-\mathrm{O}_{2}$ and $\mathrm{Fe}_{1}$ (II)- $\mathrm{N}_{4}$, respectively. ${ }^{10,24}$ These combined results conclusively confirm the formation of gasphase accessible in-plane $\mathrm{Fe}_{1}(\mathrm{II})-\mathrm{N}_{4}$ upon pyrolysis at temperatures $>600^{\circ} \mathrm{C}$.

In parallel, X-ray diffraction (XRD) measurements were conducted on the same mixture after it was subjected to pyrolysis at various temperatures. No Fe-related signals are observed throughout the temperature range up to $1000{ }^{\circ} \mathrm{C}$ Figure S7). This result indicates the lack of long-range order in all the Fe species, including the oxides observed by XAS, consistent with the lack of prominent FT-EXAFS peaks at high $\mathrm{R}$ values (Figure 1B). The ORR activities of these mixtures were assessed using a rotating disk electrode (RDE) in an $\mathrm{O}_{2}$-saturated $0.1 \mathrm{M} \mathrm{HClO}_{4}$ electrolyte. The ORR activities of the catalysts pyrolyzed at $200{ }^{\circ} \mathrm{C}$ and $400{ }^{\circ}$ Care similar to that of N-C (Figure 1E). The ORR activity improves dramatically as the pyrolysis temperature increases to $600{ }^{\circ}$, Ccoinciding with the emergence of $\mathrm{Fe}_{1}$ (II)- $\mathrm{N}_{4}$ sites. The activity continues to improve with increasing temperature up to $1000{ }^{\circ}$,Creaching a half-wave potential of $0.8 \mathrm{~V}$ (all the potentials reported here are versus the reversible hydrogen electrode and are not IR-corrected) (Figure 1E), which coincides with the increasing transformation from $\mathrm{Fe}_{1}(\mathrm{II})-\mathrm{O}_{4}$ to $\mathrm{Fe}_{1}(\mathrm{II})-\mathrm{N}_{4}$. Not only is the RDE-determined activity comparable to that of state-of-the-art Fe-N-C, ${ }^{3,6,25}$ but the intimate correlation between the increasing ORR activity and the increasing relative content of $\mathrm{Fe}_{1}(\mathrm{II})-\mathrm{N}_{4}$ in the sample provides startling evidence that the $\mathrm{Fe}_{1}$ (II)- $\mathrm{N}_{4}$ moiety is responsible for the high ORR activity of FeN-C in acidic electrolyte.

Nearly the same thermal evolution process was observed in the in-temperature XAS experiment on the MOF-based mixture: $\mathrm{FeAc}_{2}$ ferric oxides with a local octahedral $\mathrm{Fe}-\mathrm{O}_{6}$ structure $\rightarrow$ ferrous oxides tetrahedral $\mathrm{Fe}_{1}(\mathrm{II})-\mathrm{O}_{4} \rightarrow$ in-plane $\mathrm{Fe}_{1}(\mathrm{II})-\mathrm{N}_{4}$ (Supplementary Section 3). The two different but representative groups of $\mathrm{Fe}, \mathrm{N}$, and $\mathrm{C}$ precursors undergoing the same thermal evolution pathway suggests that this is likely a common pathway towards the formation of $\mathrm{Fe}_{1}(\mathrm{II})-\mathrm{N}_{4}$ during the pyrolysis of mixtures of $\mathrm{Fe}, \mathrm{N}$, and $\mathrm{C}$ precursors. This pathway is, however, missing details regarding the mechanism for transformation of tetrahedral $\mathrm{Fe}_{1}(\mathrm{II})-\mathrm{O}_{4}$ to in-plane $\mathrm{Fe}_{1}(\mathrm{II})-\mathrm{N}_{4}$. The question remains as to how the $\mathrm{Fe}_{1}(\mathrm{II})-\mathrm{O}_{4}$ transforms to a moiety with a very different local geometry and ligand environment. An alternative transformation from tetrahedral $\mathrm{Fe}-\mathrm{N}_{4}$ to active $\mathrm{FeN}_{4}$ was recently proposed to occur at temperatures $\geq 800{ }^{\circ} \mathrm{Cluring}$ the pyrolysis of Fe-doped ZIFs to form Fe-N-C catalysts. ${ }^{6}$ However, EXAFS cannot distinguish the $\mathrm{Fe}-\mathrm{O}_{4}$ structure from $\mathrm{Fe}-\mathrm{N}_{4}$ since it cannot distinguish $\mathrm{O}$ from $\mathrm{N}$ as the scattering neighbor.

To address this uncertainty, we conducted the in-temperature XAS on the mixture of $\mathrm{FeCl}_{2} \cdot 4 \mathrm{H}_{2} \mathrm{O}$ and nanoscale $\mathrm{SiO}_{2}$ powders in an environment free of $\mathrm{N}$ and $\mathrm{C}$. The $\mathrm{SiO}_{2}$ was deliberately chosen to dilute $\mathrm{FeCl}_{2} \cdot 4 \mathrm{H}_{2} \mathrm{O}$ for XAS measurements in the transmission mode, as it can also serve as a support with high thermal stability as an alternative to N-C. ${ }^{13,23}$ The thermal 
evolution involving the decomposition of $\mathrm{FeCl}_{2} \cdot 4 \mathrm{H}_{2} \mathrm{O}$ to form a species with one prominent FT peak at approximately 1.4 Åat $600^{\circ} \mathrm{G}$ as again observed (Figure 2A). The fitting of the EXAFS spectrum at $600{ }^{\circ}$ Gives an $\mathrm{Fe}-\mathrm{O}$ coordination number of $3.9 \pm$ 0.6 and bond length of $2.00 \pm 0.02 \AA$ (Table S5), thus conclusively confirming the formation of tetrahedral $\mathrm{Fe}_{1}(\mathrm{II})-\mathrm{O}_{4}$ rather than $\mathrm{Fe}_{1}(\mathrm{II})-\mathrm{N}_{4}$ or $\mathrm{Fe}_{1}(\mathrm{II})-\mathrm{C}_{4}$. More importantly, this XAS spectrum at $600{ }^{\circ}\left(\mathrm{CFeCl}_{2}-\mathrm{SiO}_{2}-600\right)$ nearly overlaps that of the $\mathrm{FeCl}_{2}$ NC-600, with trivial differences arising from a small fraction of $\mathrm{Fe}_{1}(\mathrm{II})-\mathrm{O}_{4}$ being already converted to $\mathrm{Fe}_{1}(\mathrm{II})-\mathrm{N}_{4}$ in $\mathrm{FeCl}_{2}-\mathrm{NC}-600$ (Figure 2A and Figure S12). This result verifies the formation of $\mathrm{Fe}_{1}(\mathrm{II})-\mathrm{O}_{4}$ upon the pyrolysis of $\mathrm{FeCl}_{2} \cdot 4 \mathrm{H}_{2} \mathrm{O}$ mixed with either N-C or $\mathrm{SiO}_{2}$ and, by inference, pyrolysis of the FeAc - ZIF-8 mixture.

As the temperature of the $\mathrm{FeCl}_{2}-\mathrm{SiO}_{2}$ mixture increases from $600{ }^{\circ} \mathrm{Gto} 1000{ }^{\circ} \mathrm{C}$ in the absence of N-C the $\mathrm{Fe}_{1}(\mathrm{II})-\mathrm{O}_{4}$ partly transforms to ferrous oxides and then Fe nanoparticles, rather than $\mathrm{Fe}_{1}(\mathrm{II})-\mathrm{N}_{4}$ (Figure 2A) (Supplementary Section 4). The $\mathrm{Fe}_{1}(\mathrm{II})-\mathrm{O}_{4}$ and $\mathrm{Fe}$ nanoparticles are present throughout the process of cooling to room temperature, as seen in Figure 2B, wherein the growth of the FT-EXAFS peaks is mainly attributed to the decreasing Debye-Waller factor with decreasing temperature. The XANES spectra remain largely unchanged during cooling (Figure S11B). The presence of $\mathrm{Fe}_{1}(\mathrm{II})-\mathrm{O}_{4}$ at room temperature verifies that it is a stable species when anchored onto a substrate. The observed thermal evolution pathway of the $\mathrm{FeCl}_{2}-\mathrm{SiO}_{2}$ mixture may be representative of the typical pathway for the formation of single atom catalysts supported on oxides.
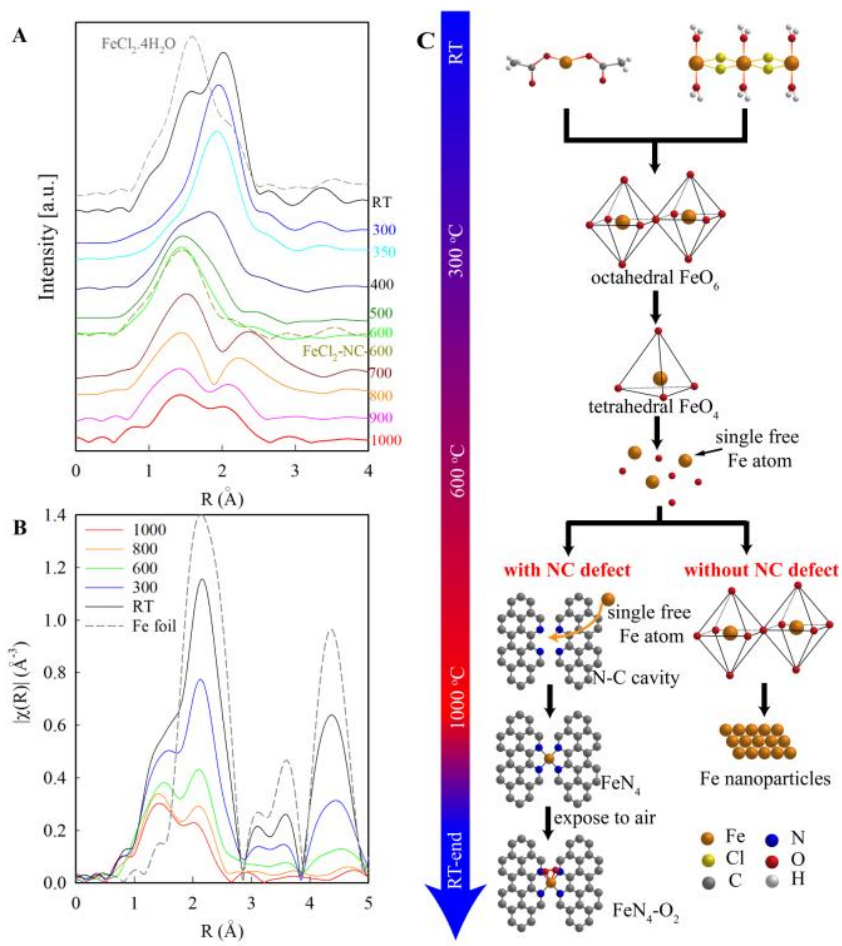

Figure 2. FT-EXAFS spectra of $\mathrm{FeCl}_{2} \cdot 4 \mathrm{H}_{2} \mathrm{O}$ mixed with $\mathrm{SiO}_{2}$ collected with (A) temperature increasing from room temperature to $1000^{\circ}$ together with and (B) cooling down to room temperature. (C) Schematic illustration of the common pathways up to $600^{\circ} \mathrm{C}$ of the thermal evolution of iron compounds during pyrolysis, and then diverging pathways at $\mathrm{T} \geq 600^{\circ} \mathrm{C}$ depending on the absence or presence of $\mathrm{N}-\mathrm{C}$ defects. Note the $\mathrm{FeN}_{4}$ configuration in the edge of two carbon planes displayed is only a representative case for illustration, without excluding other possible structures.

Collectively, the thermal evolution of the Fe precursors in the three mixtures converges to the formation of tetrahedral $\mathrm{Fe}_{1}(\mathrm{II})-\mathrm{O}_{4}$ at $600{ }^{\circ}$, Cand then diverges at higher temperatures with/without N-C (Figure 2C). This thermal decomposition generally follows the $\mathrm{Fe}-\mathrm{O}$ phase diagram that depicts the transformation of ferric oxides to ferrous oxides around $300^{\circ} \mathrm{Cin}$ an oxygen-deficient gaseous environment and then to Fe nanoparticles around $600^{\circ} \mathrm{G}$ with all the oxygen neighbors removed. ${ }^{26,27}$ A natural hypothesis deduced from the $\mathrm{Fe}-\mathrm{O}$ phase diagram is that complete removal of the oxygen neighbors from $\mathrm{Fe}_{1}(\mathrm{II})-\mathrm{O}_{4}$ leaves behind a single free $\mathrm{Fe}$ atom $\left(\mathrm{Fe}_{1}\right)$, which may form $\mathrm{Fe}_{1}(\mathrm{II})-\mathrm{N}_{4}$ if captured by the N-C defect nearby: $\mathrm{Fe}_{1}(\mathrm{II})-\mathrm{O}_{4}-\mathrm{Fe}_{1} \rightarrow$ $\mathrm{Fe}_{1}(\mathrm{II})-\mathrm{N}_{4}$, or sinter into aggregated Fe clusters in the absence of N-C defects (Figure 2C).

A unique aspect of this so-called impregnation mechanism lies in the formation of $\mathrm{Fe}_{1}$. The $\mathrm{Fe}_{1}$ is essentially a gas phase iron that expands to fill the volume available, from which we deduce that it is not necessary to mix the Fe precursors with $\mathrm{N}$ and $\mathrm{C}$ during pyrolysis to produce active Fe-N-C catalysts, as previously asserted, since the $\mathrm{Fe}_{1}$ released from the Fe precursor can diffuse or otherwise transported into N-C defects to form $\mathrm{Fe}_{1}(\mathrm{II})-\mathrm{N}_{4}$. To test this hypothesis, we developed a so-called noncontact pyrolysis procedure wherein the Fe precursor and N-C are separately placed in two boats in the furnace without direct physical contact between the two materials during pyrolysis (Figure 3A). In addition to $\mathrm{FeAc}_{2}$ and $\mathrm{FeCl}_{2} \cdot 4 \mathrm{H}_{2} \mathrm{O}$, that were shown above to transform to $\mathrm{Fe}_{1}(\mathrm{II})-\mathrm{N}_{4}$ sites when mixed with $\mathrm{N}$ and $\mathrm{C}$ precursors, $\mathrm{GFe}_{2} \mathrm{O}_{3}$ was also investigated as the Fe precursor since ferric oxides were observed at intermediate temperatures during both synthesis routes via in-temperature XAS. 

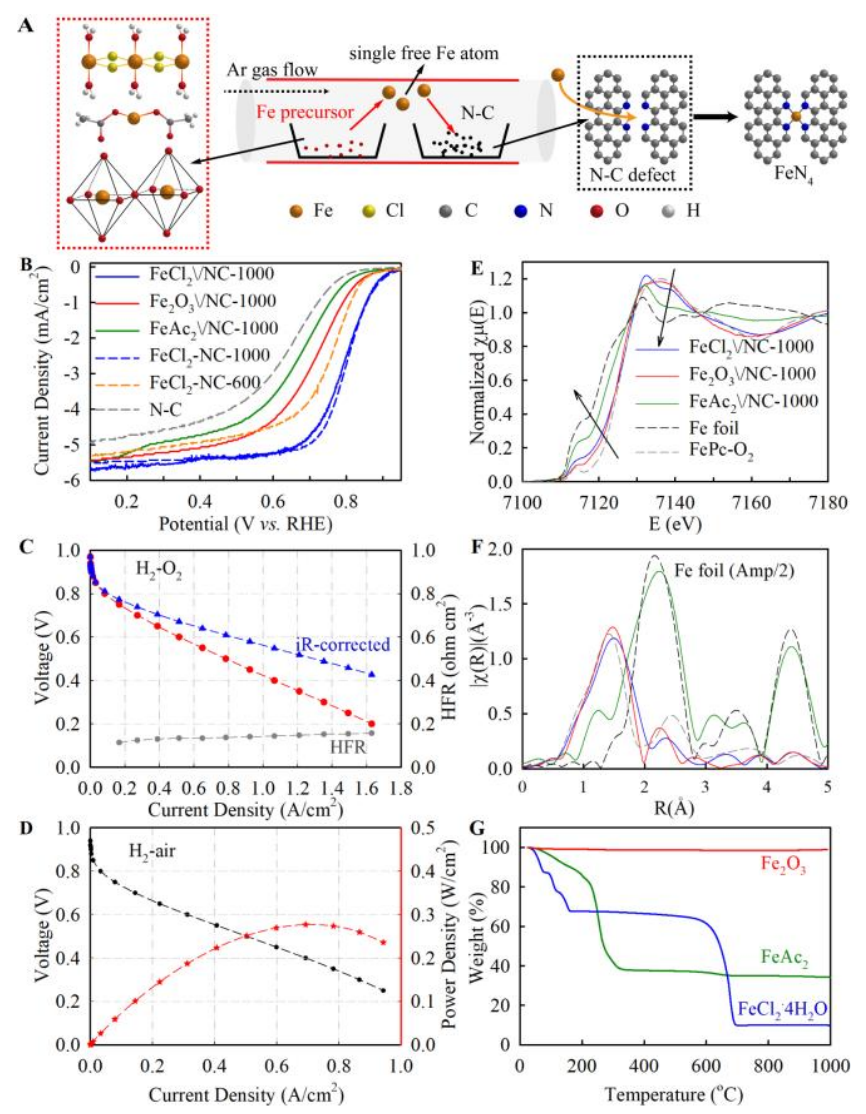

Figure 3. (A) Schematic illustration of the non-contact pyrolysis wherein the Fe precursor and N-C were separately placed in two boats in the furnace during pyrolysis with Fe placed upstream of the gas flow. (B) ORR performance of indicated catalysts. RDE polarization plots were obtained in room-temperature $\mathrm{O}_{2}$-saturated $0.1 \mathrm{M} \mathrm{HClO}_{4}$ from 0.05 to $1.05 \mathrm{~V}$ with a scan rate of $1 \mathrm{mV} \cdot \mathrm{s}^{-1}$ at a rotation rate of $1600 \mathrm{rpm}$. Solid lines represent catalysts obtained by non-contact pyrolysis; dashed line catalysts obtained by regular pyrolysis for comparison. (C) $\mathrm{H}_{2}-\mathrm{O}_{2}$ and (D) $\mathrm{H}_{2}$-air fuel cell polarization curves. Cathode: $\sim 4.0 \mathrm{mg} \cdot \mathrm{cm}^{-2}$ of $\mathrm{FeCl}_{2} \vee \mathrm{NC}-1000$; Anode: $0.3 \mathrm{mg}_{\mathrm{Pt}} \cdot \mathrm{cm}^{-2} \mathrm{Pt} / \mathrm{C}$; Membrane: NR212 membrane (Ion Power); 200 and $1000 \mathrm{~mL} \cdot \mathrm{min}^{-1}$ gas fed with $100 \% \mathrm{RH}$ at anode $\left(\mathrm{H}_{2}\right)$ and cathode $\left(\mathrm{O}_{2} /\right.$ air $)$, respectively; electrode area $5 \mathrm{~cm}^{2}$. The back pressures during the fuel cell tests are 1.0 bar reactant gas. (E) XANES and (F) FT-EXAFS spectra of the three catalysts obtained by non-contact pyrolysis, and of the Fe foil and $\mathrm{FePc}_{2} \mathrm{O}_{2}$. (G) TGA of the three $\mathrm{Fe}$ precursors including $\mathrm{FeCl}_{2} \cdot 4 \mathrm{H}_{2} \mathrm{O}, \mathrm{FeAc}_{2}$, and $\mathbf{\alpha}$ $\mathrm{Fe}_{2} \mathrm{O}_{3}$.

The ORR performance of the N-C subjected to the noncontact pyrolysis with $\mathrm{FeCl}_{2} \cdot 4 \mathrm{H}_{2} \mathrm{O}$ at $1000{ }^{\circ} \mathrm{C}$ (denoted as $\left.\mathrm{FeCl}_{2} \vee \mathrm{NC}-1000\right)$ is essentially the same as that of the mixture of $\mathrm{FeCl}_{2} \cdot 4 \mathrm{H}_{2} \mathrm{O}$ and $\mathrm{N}-\mathrm{C}$ pyrolyzed at $\left.1000{ }^{\circ} \mathrm{Q} \mathrm{FeCl}_{2}-\mathrm{NC}-1000\right)$ (Figure 3B). This catalyst also exhibits reasonably high performance in a PEMFC membrane-electrode assembly, delivering an iR-corrected current densities of $105 \mathrm{~mA} \cdot \mathrm{cm}^{-2}$ and 400 $\mathrm{mA} \cdot \mathrm{cm}^{-2}$ at $0.8 \mathrm{~V}$ and $0.7 \mathrm{~V}$, respectively, in $\mathrm{H}_{2}-\mathrm{O}_{2}$ (Figure $3 \mathrm{C}$ ), and a maximum power density of $0.28 \mathrm{~W} \cdot \mathrm{cm}^{2}$ in $\mathrm{H}_{2}$-air (Figure 3D). This relatively high performance is likely related to an enrichment of surface active sites, as expected from the vapor deposition feature of the non-contact pyrolysis. This is the first demonstration of a highly active Fe-N-C PEMFC cathode catalyst that is synthesized without mixing the Fe precursor with $\mathrm{N}$ and $\mathrm{C}$ precursors. Driven by the proof-of-concept, optimizations of the precursors, non-contact pyrolysis, and the corresponding PEMFC testing are underway in our groups.

The formation of $\mathrm{Fe}_{1}(\mathrm{II})-\mathrm{N}_{4}$ in the non-contact pyrolysis material, as reflected by the RDE and PEMFC results, is confirmed by the post-pyrolysis XAS and low temperature ${ }^{57} \mathrm{Fe}$ Mössbauer measurements. The amount of Fe deposited onto N-C is $\sim 1.5 \mathrm{wt} \%$, as estimated from the edge step of the XANES, and $\sim 1.8 \mathrm{wt} \%$ by X-ray fluorescence (XRF). The XANES aligns well with the oxygen adduct of Iron(III) phthalocyanine-tetrasulfonic acid $\left(\mathrm{FeP}_{\mathrm{C}-\mathrm{O}_{2}}\right)$ (Figure 3E). Correspondingly, the EXAFS shows a prominent $\mathrm{Fe}-\mathrm{N} / \mathrm{O}$ peak around 1.5 Åthat nearly overlaps the $\mathrm{Fe}-\mathrm{N} / \mathrm{O}$ scattering peak of $\mathrm{FePc}_{-} \mathrm{O}_{2}$ (Figure 3F). The small Fe-Fe peaks indicate the co-presence of Fe nanoparticles and oxides, which are evident in the XRD pattern (Figure S14). In agreement with the XAS, the ${ }^{57} \mathrm{Fe}$ Mössbauer spectrum collected at 5 $\mathrm{K}$ identifies four components: D1 (assigned to $\mathrm{Fe}_{1}(\mathrm{III})-\mathrm{N}_{4}-\mathrm{O}_{2}$ ), another doublet with higher isomer shift assigned to high spin $\mathrm{Fe}^{2+}, \gamma-\mathrm{Fe}$, and $\alpha-\mathrm{Fe}$ (Figure S15). Excellent fits were obtained without inclusion of a D2 doublet. These results demonstrate that the non-contact pyrolysis produces highly active Fe-N-C catalysts with predominantly $\mathrm{Fe}_{1}(\mathrm{II})-\mathrm{N}_{4}$ sites and provides support for the proposed gas-phase transport-impregnation mechanism. However, these results do not necessarily indicate that the gas phase $\mathrm{Fe}$ species is $\mathrm{Fe}_{1}$. The anhydrous $\mathrm{FeCl}_{2}$ has a relatively low boiling point of $\sim 1000{ }^{\circ} \mathrm{C}$ and possesses a vapor pressure of $\sim 1 \mathrm{~atm}$ at $1000{ }^{\circ} \mathrm{C}^{28}$ Gas phase $\mathrm{FeCl}_{2}$ may exist and be transported from the Fe-precursor boat to the N-C boat at high temperatures, forming $\mathrm{Fe}_{1}(\mathrm{II})-\mathrm{N}_{4}$ sites once contacting the N-C. When mixed with $\mathrm{N}-\mathrm{C}$, the $\mathrm{FeCl}_{2} \cdot 4 \mathrm{H}_{2} \mathrm{O}$, however, undergoes a completely different evolution pathway via the formation of iron oxides and $\mathrm{Fe}_{1}$ as illustrated in Figure 2C. Therefore, to verify the existence of gas phase $\mathrm{Fe}_{1}$, non-contact pyrolysis was also conducted on $\mathrm{GFe}_{2} \mathrm{O}_{3}$ and $\mathrm{FeAc}_{2}$ to exclude the formation of gas phase iron chlorides.

The ORR activity of the N-C subjected to the non-contact pyrolysis with $\mathrm{GFe}_{2} \mathrm{O}_{3}$ at $1000{ }^{\circ} \mathrm{C}\left(\mathrm{Fe}_{2} \mathrm{O}_{3} \vee \mathrm{NC}-1000\right)$ is much higher than that of $\mathrm{N}-\mathrm{C}$, lower than that of $\mathrm{FeCl}_{2}-\mathrm{NC}-600$, but has the same ORR onset potential (Figure 3B). These results suggest the presence of $\mathrm{Fe}_{1}(\mathrm{II})-\mathrm{N}_{4}$ sites as in $\mathrm{FeCl}_{2}-\mathrm{NC}-600$, but with lower site density. Indeed, the XANES and EXAFS of $\mathrm{Fe}_{2} \mathrm{O}_{3} \vee \mathrm{NC}-1000$ nicely overlap with those of $\mathrm{FeCl}_{2} \vee \mathrm{NC}-1000$ and $\mathrm{FePc}_{-} \mathrm{O}_{2}$ (Figure $3 \mathrm{E}$ and $3 \mathrm{~F}$ ), confirming the formation of $\mathrm{Fe}_{1}(\mathrm{II})-\mathrm{N}_{4}$. The very small XANES edge step for this material indicates that only small amounts of Fe were deposited on N-C, estimated at approximately $0.03 \mathrm{wt} \%$ by XRF. This is expected from the high thermal stability of $\mathrm{aFe}_{2} \mathrm{O}_{3}$, with a decomposition temperature higher than $1000{ }^{\circ}, \mathrm{C}$ as seen by the thermogravimetric analysis (TGA) results (Figure 3G). This validation of the non-contact pyrolysis synthesis using $\mathrm{GFe}_{2} \mathrm{O}_{3}$ further support the gas phase transport-impregnation mechanism. They also indicate that ionic compounds with stable crystalline structures are not ideal Fe precursors for Fe-N-C synthesis due to the high energies needed to break the stable Fe$\mathrm{Fe}$ bonds to release $\mathrm{Fe}_{1}$. It was shown that metal (Pd or $\mathrm{Ni}$ ) nanoparticles can release single free metal atoms that form metal- $\mathrm{N}_{4}$ sites upon impregnation into N-C defects, but this only occurs at $>1000{ }^{\circ} \mathrm{Cas}$ the competitive sintering process dominates at lower temperatures. ${ }^{29-31}$ 
The thermal stability of the ferric oxides generated in situ from $\mathrm{FeCl}_{2} \cdot 4 \mathrm{H}_{2} \mathrm{O}$ or $\mathrm{FeAc}_{2}$ mixed with $\mathrm{N}-\mathrm{C}$ is much lower than that of bulk $\mathrm{GFe}_{2} \mathrm{O}_{3}$, as it is readily reduced to $\mathrm{Fe}_{1}(\mathrm{II})-\mathrm{O}_{4}$ with its $\mathrm{Fe}-\mathrm{Fe}$ bonds cleaved in the $300{ }^{\circ} \mathrm{Go} 700{ }^{\circ} \mathrm{Ctemperature}$ range (Figure $1 \mathrm{~B}$ and Figure $\mathrm{S} 8 \mathrm{~B}$ ). Note that the ferric oxides generated in situ are invisible to XRD (Figure S7), which indicates that the clusters are ultra-small and/or amorphous. We thus deduce that the N-C disturbs the long-range crystalline structure of $\mathrm{Fe}$ oxides thereby weakening the $\mathrm{Fe}-\mathrm{Fe}$ bonds, and/or traps small clusters of Fe oxides, which have a reduced number of $\mathrm{Fe}-\mathrm{Fe}$ bonds as compared to $\mathrm{GFe}_{2} \mathrm{O}_{3}$. This promotes the transformation from $\mathrm{Fe}-\mathrm{O}_{6}$, with fewer and weakened $\mathrm{Fe}-\mathrm{Fe}$ bonds, to $\mathrm{Fe}_{1}(\mathrm{II})-\mathrm{O}_{4}$. In addition, the stabilization of $\mathrm{Fe}_{1}(\mathrm{II})-\mathrm{O}_{4}$ in the solid state by the $\mathrm{N}-\mathrm{C}$ or $\mathrm{SiO}_{2}$ substrates further promotes the crystal-to-melt-like transformation of $\mathrm{Fe}-\mathrm{O}_{6}-\mathrm{Fe}_{1}(\mathrm{II})$ $\mathrm{O}_{4}$ at much lower temperatures. Without N-C, the $\mathrm{GFe}_{2} \mathrm{O}_{3}$ with stable crystalline structures releases few $\mathrm{Fe}_{1}$ atoms and thus forms fewer $\mathrm{Fe}_{1}(\mathrm{II})-\mathrm{N}_{4}$ sites at $1000^{\circ} \mathrm{C}$

Surprisingly, the ORR performance of the N-C subjected to the non-contact pyrolysis with $\mathrm{FeAc}_{2}$ at $1000{ }^{\circ} \mathrm{G}$ s only slightly better than that of $\mathrm{N}-\mathrm{C}$, and much worse than that of $\mathrm{Fe}_{2} \mathrm{O}_{3} \vee \mathrm{NC}-1000$ (Figure 3B), indicating the absence of $\mathrm{Fe}_{1}(\mathrm{II})$ $\mathrm{N}_{4}$. Both XAS (Figure 3E and 3F) and XRD (Figure S14) of the N-C after the non-contact pyrolysis show Fe nanoparticles and oxides as the predominant Fe species. The Fe content of this material is approximately $0.5 \mathrm{wt} \%$, as estimated from both the XANES edge step and XRF. These results indicate that $\mathrm{Fe}_{1}$ atoms were released from $\mathrm{FeAc}_{2}$ and transported onto the N-C, forming $\mathrm{Fe}$ clusters rather than $\mathrm{Fe}_{1}(\mathrm{II})-\mathrm{N}_{4}$. One key difference between $\mathrm{FeAc}_{2}$ and $\mathrm{GFe}_{2} \mathrm{O}_{3}$ is that the former decomposes at $300{ }^{\circ}$,Cwhereas the latter decomposes above $1000{ }^{\circ} \mathrm{Q}$ Figure $3 \mathrm{G})$. At $300{ }^{\circ} \mathrm{C}$, sintering of $\mathrm{Fe}_{1}$ into aggregated clusters dominates, ${ }^{29}$ due to the short mean free path of $\mathrm{Fe}_{1}$ at this relatively low temperature, leading to the formation of Fe nanoparticles. In addition, $300{ }^{\circ} \mathrm{C}$ is below the temperature $\left(\sim 600{ }^{\circ} \mathrm{C}\right)$ of the transform from $\mathrm{Fe}_{1}$ (II)- $\mathrm{O}_{4}$ to $\mathrm{Fe}_{1}$ (II)- $\mathrm{N}_{4}$, and thus even if $\mathrm{Fe}_{1}$ atoms reach the $\mathrm{N}-\mathrm{C}$ substrate, they tend to form iron oxides rather than $\mathrm{Fe}_{1}(\mathrm{II})-\mathrm{N}_{4}$. These issues can be addressed by thorough mixing of $\mathrm{FeAc}_{2}$ with $\mathrm{N}$ and $\mathrm{C}$ precursors prior to pyrolysis. In the mixture, the $\mathrm{N}$-doped defects are in close proximity to the Fe sources. It can be hypothesized that N-C stabilizes $\mathrm{Fe}_{1}(\mathrm{II})-\mathrm{O}_{4}$ as the reservoir of $\mathrm{Fe}_{1}$ throughout a wide temperature range of $400-1000^{\circ}$ (Figure S8). This promotes the formation of $\mathrm{Fe}_{1}(\mathrm{II})-\mathrm{N}_{4}$, despite the short mean free path of $\mathrm{Fe}_{1}$. In comparison with $\mathrm{FeAc}_{2}, \mathrm{GFe}_{2} \mathrm{O}_{3}$ releases much fewer $\mathrm{Fe}_{1}$ atoms at much higher temperature, $\sim 1000^{\circ}$,Cand thus the mean free path of $\mathrm{Fe}_{1}$ is longer. Consequently, these $\mathrm{Fe}_{1}$ atoms can reach the N-C substrate and form $\mathrm{Fe}_{1}(\mathrm{II})-\mathrm{N}_{4}$. Similar to this proposed mechanism, Li's group recently observed the transformation of bulk $\mathrm{Pd}$ to $\mathrm{Pd}-\mathrm{N}_{4}$ at elevated temperature and accordingly proposed that this conversion was driven by the capture of mobile $\mathrm{Pd}$ atoms on the defects of N-C. ${ }^{29}$

An important implication of the non-contact pyrolysis results is that the threshold temperature for the formation of $\mathrm{Fe}_{1}(\mathrm{II})-\mathrm{N}_{4}$ of $\sim 600{ }^{\circ} \mathrm{G}$ is determined by the threshold temperature for the impregnation of $\mathrm{Fe}_{1}$ into the N-C defect $\left(\mathrm{Fe}_{1}-\mathrm{Fe}_{1}(\mathrm{II})-\mathrm{N}_{4}\right)$, rather than the release temperature of $\mathrm{Fe}_{1}$. That is, it is determined by the inherent thermal stability of $\mathrm{Fe}_{1}(\mathrm{II})-\mathrm{N}_{4}$. The $\mathrm{Fe}_{1}(\mathrm{II})-\mathrm{O}_{4}$ has a lower thermal stability as it forms and decomposes at lower temperatures. This difference in thermal stability between
$\mathrm{Fe}_{1}(\mathrm{II})-\mathrm{N}_{4}$ and $\mathrm{Fe}_{1}(\mathrm{II})-\mathrm{O}_{4}$ accounts for the competition between these two species during pyrolysis above $600{ }^{\circ} \mathrm{CT}$ he $\mathrm{Fe}_{1}(\mathrm{II})-\mathrm{N}_{4}$ gradually wins the competition as the temperature reaches 1000 ${ }^{\circ} \mathrm{C}$ This fundamental limitation determines the necessity for multiple pyrolyses with an optimized temperature of $\sim 1000{ }^{\circ} \mathrm{Co}$ drive the $\mathrm{Fe}_{1}(\mathrm{II})-\mathrm{O}_{4}-\mathrm{Fe}_{1}(\mathrm{II})-\mathrm{N}_{4}$ transformation.

\section{CONCLUSION}

We unraveled the thermal evolution pathway during the pyrolysis of Fe-N-C catalysts: Fe precursor $-\mathrm{Fe}$ oxides (octahedral $\left.\mathrm{Fe}-\mathrm{O}_{6}\right) \rightarrow$ trahedral $\mathrm{Fe}_{1}(\mathrm{II})-\mathrm{O}_{4}-\mathrm{Fe}_{1}-\mathrm{Fe}_{1}(\mathrm{II})-\mathrm{N}_{4}$. The demonstration of formation of $\mathrm{Fe}_{1}(\mathrm{II})-\mathrm{N}_{4}$ via non-contact pyrolysis (i.e., with the $\mathrm{Fe}$ precursor and nitrogen-doped carbon in separate boats) reveals the presence of gas-phase iron at mild temperatures and opens up an avenue for the synthesis of single-atom catalysts via vapor deposition approaches.

\section{ASSOCIATED CONTENT}

\section{Supporting Information}

Supporting information (PDF) includes: Experimental Section; Results and Discussion: Section 1. N-C Characterizations (Figure $\mathrm{S} 1)$; Section 2. In-temperature XAS on the mixture of $\mathrm{FeCl}_{2} \cdot 4 \mathrm{H}_{2} \mathrm{O}$ and N-C (Figure S2-S7 and Table S2-S3); Section 3. In-temperature XAS on the mixture of MOF-based mixture (Figure S8-S10 and Table S4); Section 4. In-temperature XAS on the mixture of $\mathrm{FeCl}_{2} \cdot 4 \mathrm{H}_{2} \mathrm{O}$ and $\mathrm{SiO}_{2}$ (Figure S11-S13 and Table S5); Section 5. Non-contact pyrolysis of three different Fe precursors (Figure S14). The Mössbauer spectrum of $\mathrm{FeCl}_{2} / \mathrm{NC}-1000$ measured at $5 \mathrm{~K}$ (Figure S15). This material is available free of charge via the Internet at http://pubs.acs.org.

\section{AUTHOR INFORMATION}

\section{Corresponding Author}

* Deborah J. Myers: dmyers@anl.gov

* Qingying Jia: q.jia@northeastern.edu

\section{Author Contributions}

The manuscript was written through contributions of all authors. All authors have given approval to the final version of the manuscript.

\section{Notes}

The authors declare no competing financial interests.

\section{ACKNOWLEDGMENT}

This work was supported by the US Department of Energy under award number DE-EE0008416 and DE-EE0008075. The authors acknowledge the support from the U.S. Department of Energy, Energy Efficiency and Renewable Energy, Fuel Cell Technologies Office (DOE-EERE-FCTO) through the ElectroCatalysis consortium (ElectroCat) and the DOE program managers, Dimitrios Papageorgopoulos and Simon Thompson. The in-temperature XAS experiments were performed at the Advanced Photon Source (APS), a DOE Office of Science User Facility operated for the DOE Office of Science by Argonne National Laboratory under Contract No. DE-AC02-06CH11357. The operation of MRCAT at the APS is supported by the Department of Energy and the MRCAT member institutions. We acknowledge Synchrotron SOLEIL (Gif-sur Yvette, France) for provision of synchrotron radiation facilities at beamline SAMBA for ex situ XAS experiments (proposal number 20180635). 


\section{REFERENCES}

1. Yoshida, T.; Kojima, K. Toyota MIRAI fuel cell vehicle and progress toward a future hydrogen society. Electrochem Soc Interface 2015, $24,45$.

2. James, B. D.; Huya-Kouadio, J. M.; Houchins, C.; DeSantis, D. A. Final report: mass production cost estimation of direct $\mathrm{H}_{2}$ PEM fuel cell systems for transportation applications (2012-2016); Strategic Analysis Inc., Arlington, VA (United States), 2016.

3. Chung, H. T.; Cullen, D. A.; Higgins, D.; Sneed, B. T.; Holby, E. F.; More, K. L.; Zelenay, P. Direct atomic-level insight into the active sites of a high-performance PGM-free ORR catalyst. Science 2017, 357, 479.

4. Li, J.; Chen, M.; Cullen, D. A.; Hwang, S.; Wang, M.; Li, B.; Liu, K.; Karakalos, S.; Lucero, M.; Zhang, H.; Lei, C.; Xu, H.; Sterbinsky, G. E.; Feng, Z.; Su, D.; More, K. L.; Wang, G.; Wang, Z.; Wu, G. Atomically dispersed manganese catalysts for oxygen reduction in protonexchange membrane fuel cells. Nat. Catal. 2018, 1, 935.

5. Zitolo, A.; Ranjbar-Sahraie, N.; Mineva, T.; Li, J.; Jia, Q.; Stamatin, S.; Harrington, G. F.; Lyth, S. M.; Krtil, P.; Mukerjee, S.; Fonda, E.; Jaouen, F. Identification of catalytic sites in cobalt-nitrogencarbon materials for the oxygen reduction reaction. Nat. Commun. 2017, 8, 957.

6. Zhang, H.; Hwang, S.; Wang, M.; Feng, Z.; Karakalos, S.; Luo, L.; Qiao, Z.; Xie, X.; Wang, C.; Su, D.; Shao, Y.; Wu, G. Single atomic iron catalysts for oxygen reduction in acidic media: particle size control and thermal activation. J. Am. Chem. Soc. 2017, 139, 14143.

7. Lefèvre, M.; Proietti, E.; Jaouen, F.; Dodelet, J.-P. Iron-based catalysts with improved oxygen reduction activity in polymer electrolyte fuel cells. Science 2009, 324, 71.

8. Proietti, E.; Jaouen, F.; Lefèvre, M.; Larouche, N.; Tian, J.; Herranz, J.; Dodelet, J.P. Iron-based cathode catalyst with enhanced power density in polymer electrolyte membrane fuel cells. Nat. Commun. 2011, 2, 416.

9. Banham, D.; Kishimoto, T.; Zhou, Y.; Sato, T.; Bai, K.; Ozaki, J.i.; Imashiro, Y.; Ye, S. Critical advancements in achieving high power and stable nonprecious metal catalyst-based MEAs for real-world proton exchange membrane fuel cell applications. Sci. Adv. 2018, 4, 7180 .

10. Li, J.; Ghoshal, S.; Liang, W.; Sougrati, M.-T.; Jaouen, F.; Halevi, B.; McKinney, S.; McCool, G.; Ma, C.; Yuan, X.; Ma, Z.-F.; Mukerjee, S.; Jia, Q. Structural and mechanistic basis for the high activity of Fe-NC catalysts toward oxygen reduction. Energy Environ. Sci. 2016, 9, 2418.

11. Gupta, S.; Tryk, D.; Bae, I.; Aldred, W.; Yeager, E. Heat-treated polyacrylonitrile-based catalysts for oxygen electroreduction. J. Appl. Electrochem. 1989, 19, 19.

12. Jia, Q.; Ramaswamy, N.; Tylus, U.; Strickland, K.; Li, J.; Serov, A.; Artyushkova, K.; Atanassov, P.; Anibal, J.; Gumeci, C.; Barton, S. C.; Sougrati, M.-T.; Jaouen, F.; Halevi, B.; Mukerjee, S. Spectroscopic insights into the nature of active sites in iron-nitrogen-carbon electrocatalysts for oxygen reduction in acid. Nano Energy 2016, 29, 65.

13. Serov, A.; Artyushkova, K.; Niangar, E.; Wang, C.; Dale, N.; Jaouen, F.; Sougrati, M.-T.; Jia, Q.; Mukerjee, S.; Atanassov, P. Nanostructured non-platinum catalysts for automotive fuel cell application. Nano Energy 2015, 16, 293.

14. Tylus, U.; Jia, Q.; Strickland, K.; Ramaswamy, N.; Serov, A.; Atanassov, P.; Mukerjee, S. Elucidating oxygen reduction active sites in pyrolyzed metal-nitrogen coordinated non-precious-metal electrocatalyst systems. J. Phys. Chem. C 2014, 118, 8999.

15. Strickland, K.; Miner, E.; Jia, Q.; Tylus, U.; Ramaswamy, N.; Liang, W.; Sougrati, M.-T.; Jaouen, F.; Mukerjee, S. Highly active oxygen reduction non-platinum group metal electrocatalyst without direct metal-nitrogen coordination. Nat. Commun. 2015, 6, 7343.

16. Ramaswamy, N.; Tylus, U.; Jia, Q.; Mukerjee, S. Activity descriptor identification for oxygen reduction on nonprecious electrocatalysts: linking surface science to coordination chemistry. $J$. Am. Chem. Soc. 2013, 135, 15443.

17. Olson, T. S.; Pylypenko, S.; Fulghum, J. E.; Atanassov, P. Bifunctional oxygen reduction reaction mechanism on non-platinum catalysts derived from pyrolyzed porphyrins. J. Electrochem. Soc. 2010, 157, B54.

18. Deng, D.; Yu, L.; Chen, X.; Wang, G.; Jin, L.; Pan, X.; Deng, J.; Sun, G.; Bao, X. Iron encapsulated within pod-like carbon nanotubes for oxygen reduction reaction. Angew. Chem. Int. Ed. 2013, 52, 371.

19. Fei, H.; Dong, J.; Feng, Y.; Allen, C. S.; Wan, C.; Volosskiy, B.; Li, M.; Zhao, Z.; Wang, Y.; Sun, H.; An, P.; Chen, W.; Guo, Z.; Lee, C.; Chen, D.; Shakir, I.; Liu, M.; Hu, T.; Li, Y.; Kirkland, A. I.; Duan, $\mathrm{X}$.; Huang, Y. General synthesis and definitive structural identification of $\mathrm{MN}_{4} \mathrm{C}_{4}$ single-atom catalysts with tunable electrocatalytic activities. Nat. Catal. 2018, 1, 63

20. Zitolo, A.; Goellner, V.; Armel, V.; Sougrati, M.-T.; Mineva, T.; Stievano, L.; Fonda, E.; Jaouen, F. Identification of catalytic sites for oxygen reduction in iron- and nitrogen-doped graphene materials. Nat. Mater. 2015, 14, 937.

21. Artyushkova, K.; Serov, A.; Rojas-Carbonell, S.; Atanassov, P. Chemistry of multitudinous active sites for oxygen reduction reaction in transition metal-nitrogen-carbon electrocatalysts. J. Phys. Chem. C 2015, 119, 25917.

22. Matter, P. H.; Wang, E.; Arias, M.; Biddinger, E. J.; Ozkan, U. S. Oxygen reduction reaction activity and surface properties of nanostructured nitrogen-containing carbon. J. Mol. Catal. A: Chem. 2007, 264, 73.

23. Jackson, W. E.; Mustre de Leon, J.; Brown Jr., G. E.; Waychunas, G. A.; Conradson, S. D.; Combes, J.-M. High-temperature XAS study of $\mathrm{Fe}_{2} \mathrm{SiO}_{4}$ liquid: reduced coordination of ferrous iron. Science 1993, 262, 229.

24. Kneebone, J. L.; Daifuku, S. L.; Kehl, J. A.; Wu, G.; Chung, H. T.; Hu, M. Y.; Alp, E. E.; More, K. L.; Zelenay, P.; Holby, E. F.; Neidig, M. L. A combined probe-molecule, Mössbauer, nuclear resonance vibrational spectroscopy, and density functional theory approach for evaluation of potential iron active sites in an oxygen reduction reaction catalyst. J. Phys. Chem. C 2017, 121, 16283.

25. Beltrán, D. E.; Litster, S. Half-wave potential or mass activity? characterizing platinum group metal-free fuel cell catalysts by rotating disk electrodes. ACS Energy Letters 2019, 4, 1158.

26. Channei, D.; Phanichphant,; S.; Nakaruk, A.; Mofarah, S. S.; Koshy, P.; Sorrell, C. C. Aqueous and surface chemistries of photocatalytic Fe-doped $\mathrm{CeO}_{2}$ nanoparticles. Catalysts 2017, 7, 45.

27. Ketteler, G.; Weiss, W.; Ranke, W.; Schlögl, R. Bulk and surface phases of iron oxides in an oxygen and water atmosphere at low pressure. Phys. Chem. Chem. Phys. 2001, 3, 1114.

28. Kanari, N.; Mishra, D.; Filippov, L.; Diot, F.; Mochón, J.; Allain, E. Kinetics of hematite chlorination with $\mathrm{Cl}_{2}$ and $\mathrm{Cl}_{2}+\mathrm{O}_{2}$ : Part I. Chlorination with Cl2. Thermochim. Acta 2010, 497, 52.

29. Wei, S.; Li, A.; Liu, J.-C.; Li, Z.; Chen, W.; Gong, Y.; Zhang, Q.; Cheong, W.-C.; Wang, Y.; Zheng, L.; Xiao, H.; Chen, C.; Wang, D.; Peng, Q.; Gu, L.; Han, X.; Li, J.; Li, Y. Direct observation of noble metal nanoparticles transforming to thermally stable single atoms. Nat. Nanotechnol. 2018, 13, 856.

30. Yang, J.; Qiu, Z.; Zhao, C.; Wei, W.; Chen, W.; Li, Z.; Qu, Y.; Dong, J.; Luo, J.; Li, Z.; Wu, Y. In situ thermal atomization to convert supported nickel nanoparticles into surface-bound nickel single-atom catalysts. Angew. Chem. Int. Ed. 2018, 57, 14095.

31. Zhang, C.; Zhang, W.; Zheng, W. Pinpointing single metal atom anchoring sites in carbon for oxygen reduction: Doping sites or defects? Chinese J. Catal. 2018, 39, 4. 
For Table of Contents only

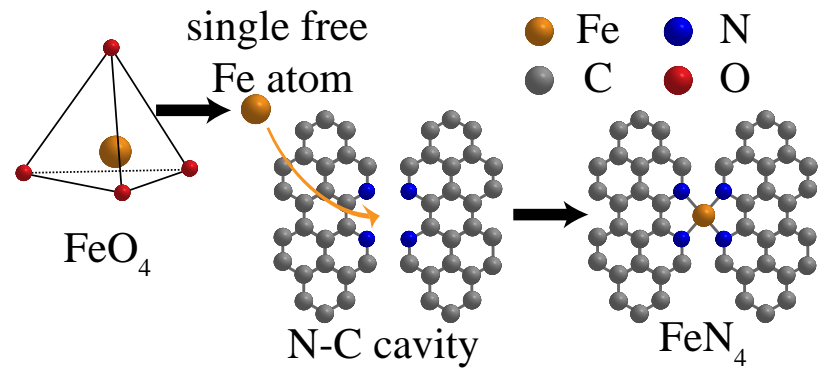

